\title{
QUANTITATIVE OXIDATION OF NUTRIENTS IN BROILER TREATED WITH B-AGONIST L-644,969
}

\author{
Maksudi ${ }^{\prime}$
}

\begin{abstract}
Effects of B-agonist L-644,969 on nutrient oxidation were evaluated in broiler chickens allocated into twelve cages with six chicken per cage during the first week and three chickens in the following five weeks of the experiment. The B-agonist L- 644,969 was given at the doses of 0 (T0), 025 (T1) and 10 (T2) ppm. The contribution of each nutrient to the total heat production showed that $L-644,969$ decreased the protein oxidation and increased fat oxidation. Lipogenesis from carbohydrate made up the main contribution (69 to $74 \%$ ) to the total fat retention In contrast, fat retention from protein $(6$ to $8 \%$ ) was the minor contribution, and there was no difference between control and treatment groups. The conversion of dietary fat to fat stored directly in the body ranged from $24 \%$ in the control to $8 \%$ at $1.0 \mathrm{ppm}$ level. This study supports previous findings that the $\beta$-agonist L-644,969 increased protein utilization and decreased fat deposition
\end{abstract}

(Key words: B-agonist L-644,969, Nutrient oxidation, Broiler, Heat production, Lipogenesis, Fat retention).

\section{KUANTITATIF OKSIDASI NUTRISI PADA AYAM BROHLER YANG MENDAPAT PERLAKUAN DENGAN B-AGONIST 1-644,969}

\section{INTISARI}

Pengaruh B-agonist L-644,969 terhadap oksidasi nutrisi dievaluasi pada ayam pedaging yang ditempatkan pada 12 kandang koloni dengan 6 ekor ayam setiap kandangnya pada minggu pertama percobaan kemudian dikurangi menjadi menjadi 3 ekor ayam pada lima minggu berikutnya. B-agonist L-644,969 diberikan pada dosis 0 ppm (T0), 0,25 ppm (T1) dan 1.0 ppm (T2) Kontribusi setiap nutrisi terhadap total produksi panas menunjukkan bahwa B-agonist L644,969 menurunkan oksidasi protein dan meringkatkan oksidasi panas, Lipogenesis dari karbohidrat memberikan sumbangan terbesar ( 69 sampai 74\%) dari total retensi lemak. Sebaliknya retensi lemak dari protein hanya memberikan sumbangan yang kecil (6 sampai $8 \%$ ). dan ternvata tidak ada perbedaan antara konirol (TO) dan ayam yang mendapat perlakuan Konversi diet lemak yang langsung terhadap lemak tubuh berkisar antara $24 \%$ pada To sampai $8 \%$ pada T1. Disimpulkan bahwa penelitian ini sesuai dengan penelititan-penelititan sebelumnya bahwa Bagonist 1,-644,969 meningkatkan pemanfaatan protein dan menurunkan penimbunan lemak tubuh

(Kata kunci: B-agonist L-644,969, Nutrient oxidation, Broiler, Heat production, Lipogenesis, Fat retention)

Buletin Peternakan 24 (3): 94 - 102, 2000

\footnotetext{
'Fakultas Peternakan Universitas Jambi, Jambi.
} 


\section{Introduction}

Most recent work on the use of Badrenergic agonists has been focussed on their abilities to improve food efficiency, promote protein retention and reduce fat deposition in growing animals. Some work associated with energy metabolism and heat production has also concerned in pigs (Yen et al, 1990), cattle (Moloney et al., 1990; Chwalibog et al., 1996), sheep (Rikhardsson el al., 1991) and broilers (Xiyi et al., 1994). However, no attention has been paid to the potential effects of B-adrenergic agonists on quantitative relations between digested nutrients and their final output from catabolic and anabolic processes in poultry. The experiment concerning the effect of $\mathrm{B}$-agonists on quantitative nutrient oxidation was done by Chwalibog et al (1996) in growing calves. Thus, the objectives of the this study were to investigate the quantitative oxidation of dietary carbohydrate, protein, fat and the contribution of each nutrient to fat retention in growing chickens treated with B-agonist L-644,969.

\section{Materials and Methods}

Male broiler chickens, Ross Cobb 208 obtained from a commercial hatchery, were used in this experiment. Seventy-two day-old chicks of one day of age were allocated into twelve cages with six chicks per cage during the first week and three chicks in the following five weeks of the experiment. The cages were equipped with feeders and two hanging nipple drinkers supplying water through pipes positioned at the back of the cages. Droppings were fell through wire mesh floors into the dropping trays. The diameter of the wire used in the first period was $1.0 \mathrm{~cm}$ whereas $2.0 \mathrm{~cm}$ was used in the later periods.

Chickens were fed a commercial diet and given ad libitum for a five-day collection period. Food residues were weighed, mixed and used for dry matter (DM) determination to correct the differences in DM content between food and food residues. Droppings were collected daily before feeding and analysed for DM, crude protein (CP), fat, ash and energy according to methods described by Thorbek (1980). The values of gross energy (GE) were obtained by means of calorimetric bombs

The B-adrenergic agonist, L-644,969 (R,R isomer of 6-amino-alpha\{[(1-methyl-3phenylpropyl) amino] methyl\}-3-pyridine methanol dihydrochloride), was provided by Merck and $\mathrm{Co}$, Inc. (Rahway, NJ), and the amount of L-644,969 was given orally in water dilution with a micro pipette injection. The treatment levels of B-agonist were control, i.e. $0 \mathrm{ppm}$ (T0), together with $0.25 \mathrm{ppm}$ (T1) and $1.0 \mathrm{ppm}$ (T2) based on the food intake of the preliminary experimental series

A 22 to 24-hour respiration measurement was made in the middle of each five-day collection period using an open-air circulation respiration unit. In respiration chambers, the temperature and humidity were automatically controlled The air flow in the system is measured by the differential pressure principle, and the composition of outgoing air is measured using an infrared gas analyser Uras (Hartmann and Braun, Germany) for carbon dioxide and a paramagnetic analyser Magnos (Hartmann and Braun, Germany) for oxygen. The gas exchange was calculated from the difference between the concentration of atmospheric gas entering the chamber and the gas leaving the chamber. The difference in gas concentration was multiplied by the rate of flow at which the gas was withdrawn from the chamber.

An outline of measurements and calculations are shown in Figure 1. The quantitative data measurements of substrate oxidation were calculated from measurements of gaseous exchange and nitrogen excretion in urine based on Brouwer's equation (1958) and later validated for pigs by Chwalibog and Thorbek (1992) and Chwalibog et al. (1995). The following terminology and calculations were used: 


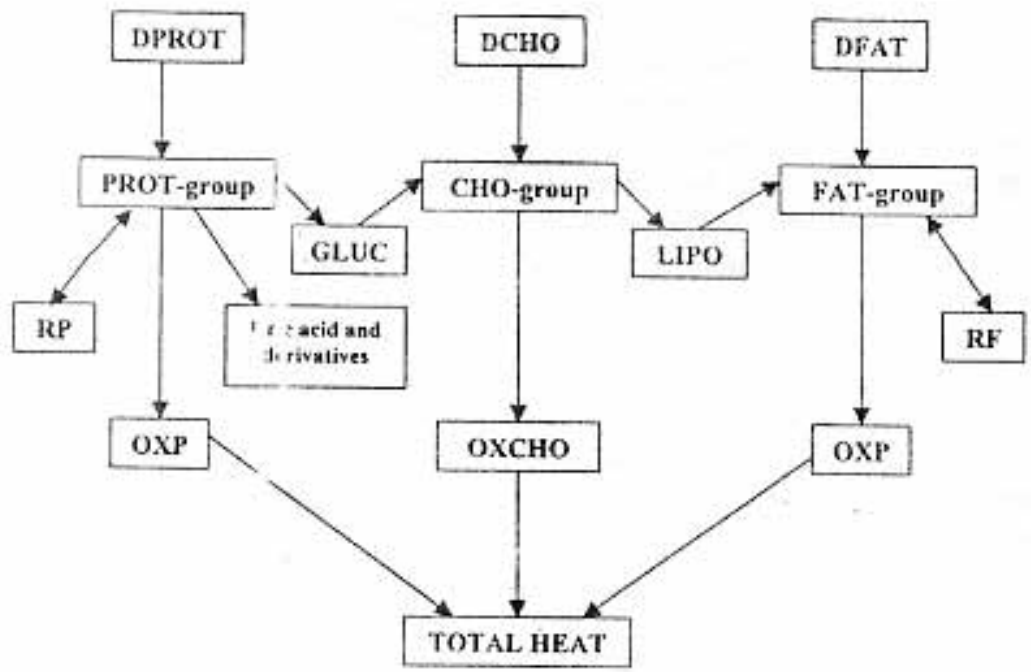

Figure 1. Model of nutrient oxidation and retention (From Chwalibog, 1997).

\section{Protein metabolism}

IP, $\mathrm{g}$ (ingested protein) $=\mathrm{IN}, \mathrm{g}$ (ingested nitrogen) $\times 6.25$

DRP, g (droppings protein) $=$ DRN, g (droppings nitrogen) $\times 6.25$

RP, g (retained protein $)=I P-D R P$

FN, $g$ (faecal nitrogen $)=\mathbb{I N} \times 0.20$, assuming digestibility is $80 \%$

$\mathrm{UN}, \mathrm{g}$ (urinary nitrogen) $=\mathrm{DRN}-\mathrm{FN}$

DPROT, $\mathrm{kJ}$ (digested protein) $=$ IP $\times 0.80 \times$

23.86

PROT-group, $k J$ (protein group) $=$ DPROT

OXP, kJ (oxidized protein) $=U N, g \times 6.25 \times$ 18.42

$R P, k J=R P, g \times 23.86$

GLUC, kJ (gluconeogenesis) = DPROT, $\mathrm{kJ}$ OXP, kJ - RP, kJ

\section{Carbohydrate metabolism}

$\mathrm{DCHO}, \mathrm{kJ}$ (digested carbohydrate) $=\mathrm{ME} \times$ 1.05 - DPROT, $\mathrm{kJ}$ - (DFAT, g (digested fat) $\mathrm{x}$ 39.76 ), assuming $\mathrm{DE}$ is $5 \%$ higher than $\mathrm{ME}$ $\mathrm{OXCHO}, \mathrm{kJ}$ (oxidized carbohydrate) $=(-2.968$ $\left.\times \mathrm{O}_{2}, 1-4.174 \times \mathrm{CO}_{2}, 1-2.446 \times \mathrm{UN}, \mathrm{g}\right) \times$ 17.58

CHO-group, $\mathrm{kJ}=\mathrm{DCHO}, \mathrm{kJ}+\mathrm{GLUC}, \mathrm{kJ}$
LIPO, kJ (lipogenesis) $=$ CHO-group, $\mathrm{kJ}$ $\mathrm{OXCHO}, \mathrm{kJ}$

\section{Fat metabolism}

DFAT, $\mathrm{kJ}=$ DFAT, $\mathrm{g} \times 39.76^{\circ}$

FAT-group, $k J=D F A T, k J+L I P O, k J$

OXF. $\mathrm{kJ}=\left(1.719 \times \mathrm{O}_{2}, 1-1.719 \times \mathrm{CO}_{2}, \mathrm{I}\right.$. $1963 \times \mathrm{UN}, \mathrm{g}) \times 39.76$

$\mathrm{RF}, \mathrm{kJ}$ (retained fat) $=\mathrm{FAT}$-group, $\mathrm{kJ}-\mathrm{OXF}, \mathrm{kJ}$

\section{Heat production}

$\mathrm{HE}(\mathrm{RQ}), \mathrm{kJ}=16.18 \times \mathrm{O}_{2}, \mathrm{I}+5.02 \times \mathrm{CO}_{2}, \mathrm{I}$. $5.99 \times \mathrm{UN}, \mathrm{g}$

Contribution of each nutrient metabolism to fat retention

$\mathrm{RF}(\mathrm{P}), \%$ (retained fat from protein) $=(\mathrm{DP}, \mathrm{kJ}$

- OXP, kJ - RP, kJ)/RF, kJ

$\mathrm{RF}(\mathrm{CHO}), \%$ (retained fat from carbohydrate)

$=(\mathrm{DCHO}, \mathrm{kJ}-\mathrm{OXCHO}, \mathrm{kJ}) / \mathrm{RF}, \mathrm{kJ}$

$\mathrm{RF}(\mathrm{F}), \%$ (retained fat from fat) $=(\mathrm{DF}, \mathrm{kJ}-$ $\mathrm{OXF}, \mathrm{kJ}) / \mathrm{RF}, \mathrm{kJ}$

\section{Measurements and statistical analysis}

The measurements included protein balance, gaseous exchange, and energy balance. All measurements were reported in relatiol

Since !

betwee

combir

statisti

ANOV

arrange

randon

proced

multipl

treatme

tion of

$Y_{3, k}$

$B_{i}$

$\square_{j}=$

(B)

$\mathbf{e}_{i j i}$

Utiliza

shown and $R$ betwee signific in $\mathrm{OXF}$

N

DP, kJ

RP, kJ OXP,

GLUC

RP/DP

$\mathrm{OXP} / \mathrm{D}$

GLUC

$\mathrm{a}-\mathrm{b}$ Mea 
relation to metabolic body weight ( $\mathrm{W}, \mathrm{kg}^{0.75}$ ). Since no parameters were statistically different between series $B$ and $C$, the data were combined into one data set experiments. The statistical analysis used was the unbalanced ANOVA procedure appropriate for factorial arrangement of treatments in completely randomized block design using the GLM procedure (SAS Institute, 1988). Duncan's multiple range test was used to compare treatment means. The mathematical description of an observation is given by

$$
\begin{aligned}
& \mathrm{Y}_{i j k}=\square+B_{i}+\mathrm{Q}_{j}+(B \square)_{i j}+\mathrm{e}_{r i p k} \\
& \square=\text { treatment mean } \\
& B_{1}=\text { effect of period, } \\
& \Pi_{j}=\text { effect of treatment } \\
& (B \square)_{y}=\text { interaction between period and } \\
& \text { treatment } \\
& \mathrm{e}_{p(p)}=\text { experimental error }
\end{aligned}
$$

\section{Results}

\section{Utilization of nutrients}

The summary of protein utilization is shown in Table 1. Whereas digestible protein and RP were not significantly different between the groups, OXP and GLUC were significantly different $(\mathrm{P}<0.05)$. The decrease in OXP in chickens at the dose of 0.25 was more pronounced than in chickens at the higher dose of $\mathrm{B}$-agonist, and a similar trend was shown for the result in gluconeogenesis. The proportions of RP, OXP and GLUC to DP were significantly different in all groups $(P<0.05)$. The proportion RP/DP increased at the dose of $0.25 \mathrm{ppm}$ but diminished at the dose of $1.0 \mathrm{ppm}$. Adverse responses were shown in OXP/DP and GLUC/DP, but the decrease at the dose of $0.25 \mathrm{ppm}$ was not followed by a further decrease at the dose of $1.0 \mathrm{ppm}$. Nonetheles, the response was still lower than the control. Since DP was not different, the patterns of OXP/DP and GLUC/DP followed the patterns of OXP and GLUC, respectively.

The summary of carbohydrate utilization is shown in Table 2. Values for digested carbohydrate, $\mathrm{CHO}$-group, OXCHO and the use of the CHO-group for oxidation and lipogenesis were not significantly different $(P>0.05)$. The mean values of LIPO were numerically decreased in treated groups but were not statistically different due to high variability of the LIPO. The response showed that at the dose of $1.0 \mathrm{ppm}$, the value of LIPO was increased compared with the lower dose (TI) but was still lower than the control.

Table 1. Means of retained protein (RP), oxidized protein (OXP) and gluconeogenesis (GLUC), and their proportions to digested protein (DP)

\begin{tabular}{lccccc}
\hline & $\begin{array}{c}\text { T0 } \\
(0 \mathrm{ppm})\end{array}$ & $\begin{array}{c}\mathrm{T} 1 \\
(0.25 \mathrm{ppm})\end{array}$ & $\begin{array}{c}\text { T2 } \\
(1.0 \mathrm{ppm})\end{array}$ & SEM & Significance \\
\hline $\mathrm{N}$ & 24 & 25 & 29 & & \\
$\mathrm{DP}, \mathrm{kJ}$ & 505 & 497 & 494 & 35.2 & $\mathrm{~ns}$ \\
$\mathrm{RP}, \mathrm{kJ}$ & 378 & 382 & 372 & 34.3 & $\mathrm{~ns}$ \\
OXP, kJ & $98.1 \mathrm{a}$ & $88.6 \mathrm{~b}$ & $93.8 \mathrm{ab}$ & 9.72 & $*$ \\
GLUC, kJ & $290 \mathrm{a}$ & $26.2 \mathrm{~b}$ & $27.7 \mathrm{ab}$ & 2.86 & $*$ \\
RPDPP, \% & $59.8 \mathrm{a}$ & $61.4 \mathrm{~b}$ & $60.3 \mathrm{ab}$ & 2.08 & $*$ \\
OXP/DP, \% & $19.5 \mathrm{a}$ & $17.9 \mathrm{~b}$ & $19.1 \mathrm{ab}$ & 2.10 & $*$ \\
GLUC/DP, \% & $5.8 \mathrm{a}$ & $5.3 \mathrm{~b}$ & $5.6 \mathrm{ab}$ & 0.59 & $*$ \\
\hline
\end{tabular}

a-b Means within rows followed by different letters are significantly different ${ }^{*}(\mathrm{P}<0.05)$; ns, not significant $(\mathrm{P}>0.05)$ 
Table 2, Means of digested carbohydrate (DCHO) and the proportions of oxidized carbohydrate (OXCHO) and lipogenesis (LIPO) to carbohydrate group (CHO-group)

\begin{tabular}{lccccc}
\hline & $\begin{array}{c}\text { T0 } \\
(0 \mathrm{ppm})\end{array}$ & $\begin{array}{c}\mathrm{T} 1 \\
(0.25 \mathrm{ppm})\end{array}$ & $\begin{array}{c}\mathrm{T} 2 \\
(1.0 \mathrm{ppm})\end{array}$ & SEM & Significance \\
\hline $\mathrm{N}$ & 24 & 25 & 29 & & \\
DCHO, kJ & 855 & 847 & 830 & 64.6 & $\mathrm{~ns}$ \\
CHO-group, kJ & 884 & 873 & 858 & 64.8 & $\mathrm{~ns}$ \\
OXCHO, kJ & 549 & 570 & 544 & 89.3 & $\mathrm{~ns}$ \\
LIPO, kJ & 335 & 303 & 314 & 113.5 & $\mathrm{~ns}$ \\
OXCHO/CHO-group, $\%$ & 61.9 & 65.4 & 63.9 & 12.60 & $\mathrm{~ns}$ \\
LiPO/CHO-group, $\%$ & 33.1 & 34.6 & 36.1 & 11.60 & $\mathrm{~ns}$ \\
\hline
\end{tabular}

ns, not significant $(\mathrm{P}>0.05)$

Table 3. Means of digested fat (DF and the proportions of oxidized fat (OXF) and retained fat (RF) to fat group (Fat-group)

\begin{tabular}{lccccc} 
& T0 & T1 & T2 & & \\
& $(0 \mathrm{ppm})$ & $(0.25 \mathrm{ppm})$ & $(1.0 \mathrm{ppm})$ & SEM & Significance \\
\hline $\mathrm{N}$ & 24 & 25 & 29 & & \\
DF, kJ & 197 & 191 & 192 & 12.7 & ns \\
Fat-group, kJ & 531 & 494 & 506 & 119.9 & ns \\
OXF, kJ & $91 \mathrm{a}$ & $112 \mathrm{ab}$ & $165 \mathrm{~b}$ & 107.5 & $*$ \\
RF, kJ & $440 \mathrm{a}$ & $382 \mathrm{~b}$ & $341 \mathrm{~b}$ & 74.40 & $* *$ \\
OXF/Fat-group, \% & $160 \mathrm{a}$ & $21.7 \mathrm{ab}$ & $28.9 \mathrm{~b}$ & 13.65 & $*$ \\
RF/Fat-group, \% & $84.0 \mathrm{a}$ & $78.3 \mathrm{ab}$ & $71.6 \mathrm{~b}$ & 13.46 & $*$ \\
\hline
\end{tabular}

a-b Means within rows followed by different letters are significantly different ${ }^{*}(P<0.05)$; ${ }^{* *}(\mathrm{P}<0.01)$; ns, not significant $(\mathrm{P}>0.05)$

The results of the fat utilization are given in Table 3 . The data showed that L644,969 resulted in an increase in OXF up to the dose of $1.0 \mathrm{ppm}$ in spite of there being no effect on the FAT-group. Therefore, L644,969 given at the dose $0.25 \mathrm{ppm}$ decreased $\mathrm{RF}$, and the response at the dose of $1.0 \mathrm{ppm}$ declined but remained lower $(P<0,01)$ than in the control group. The oxidation of fat and $\mathrm{OXF} / \mathrm{FAT}$-group at the dose of $1.0 \mathrm{ppm}$ increased as the dose of $B$-agonist was increased $(\mathrm{P}<0.01)$. Although at the dose of $0.25 \mathrm{ppm}$ the value was numerically higher than the control, this value was not statistically different.
In all groups the main source for fat retention was carbohydrate. The values of retained fat from carbohydrate, $\mathrm{RF}(\mathrm{CHO})$, in relation to RF were $69.5,72.5$ and $84.0 \%$ for $\mathrm{TO}, \mathrm{T} 1$ and $\mathrm{T} 2$, respectively. In contrast to the increase of $\mathrm{RF}(\mathrm{CHO})$, the mean values of retained fat from fat, $R F(F)$, decreased as the dose of L-644,969 was increased. The RF(F) values of T0, T1 and T2 were 23.9, 20.6 and $7.9 \%$, respectively. The smallest contribution to the total fat retention was protein. The values of retained fat from protein, $R F(P)$, were $6.6,6.9$ and $8.1 \%$ for $\mathrm{T} 0, \mathrm{~T} 1$ and $\mathrm{T} 2$, respectively. 
Table 4. Means of respiratory quotient (RQ), metabolizable energy (ME) and the proportions of oxidized protein (OXP), oxidized carbohydrate (OXCHO) and oxidized fat (OXF) to heat production (HE)

\begin{tabular}{lccccc}
\hline & T0 & T1 & T2 & & \\
& $(0 \mathrm{ppm})$ & $(0.25 \mathrm{ppm})$ & $(1.0 \mathrm{ppm})$ & SEM & Significance \\
\hline $\mathrm{N}$ & 24 & 25 & 29 & & \\
$\mathrm{RQ}$ & 0.93 & 0.93 & 0.92 & 0.035 & $\mathrm{~ns}$ \\
$\mathrm{HE}, \mathrm{kJ}$ & $738 \mathrm{a}$ & $771 \mathrm{ab}$ & $802 \mathrm{~b}$ & 50.2 & $* *$ \\
$\mathrm{ME}, \mathrm{kJ}$ & 1483 & 1462 & 1443 & 103.1 & $\mathrm{~ns}$ \\
$\mathrm{OXP} / \mathrm{HE}, \%$ & $13.3 \mathrm{a}$ & $11.6 \mathrm{~b}$ & $11.8 \mathrm{~b}$ & 1.37 & $*$ \\
OXCHO/HE, \% & 73.5 & 73.5 & 68.6 & 12.14 & $\mathrm{~ns}$ \\
OXF/HE, \% & $13.2 \mathrm{a}$ & $14.9 \mathrm{ab}$ & $19.6 \mathrm{~b}$ & 1.22 & + \\
\hline
\end{tabular}

a-b Means within rows followed by different letters are significantly different $+(\mathrm{P}<01)$; ${ }^{* *}(\mathrm{P}<0.01) ; \mathrm{ns}$, not significant $(\mathrm{P}>0.05)$

\section{Oxidation of nutrients}

Results on nutrient oxidation are shown in Table 4 and. The respiratory quotient (RQ) was between 0.94 and 0.92 and was not different between the two groups $(\mathrm{P}>0.05)$. L644,969 administered at $0.25 \mathrm{ppm}$ produced a significant increase $(P<0.01)$ in $\mathrm{HE}$, and at the higher dose of $1.0 \mathrm{ppm}$ HE remained greater than for the control chicken. Heat production derived from oxidation of protein in relation to the total heat production (OXP/HE) decreased $(\mathrm{P}<0.01)$ in treated chicken. The mean values were between 11.6 and $13.3 \%$ of the total $\mathrm{HE}$. The mean values of OXCHO comprised between 74.0 and $78.3 \%$, and the mean values of OXF were between 19.1 and $23.8 \%$ of the total heat production. There was no significant difference $(P>0.05)$ in heat production from carbohydrate in relation to total heat production (OXCHO/HE), but $\mathrm{OXF} / \mathrm{HE}$ was statistically different $(P<0,1)$ between the two groups.

\section{Discession}

The use of the RQ method for estimating heat production is subjected to some uncertainty. In normally growing animals consuming excess energy, values above 1.0 may occur due to the lipogenesis from carbohydrate. Under such conditions, triglyce- rides are mobilized from adipose tissue and fatty acids are oxidized in various tissues, but the rate of fatty acid synthesis from carbohydrate is greater than the rate of fatty acid oxidation (Brody, 1994). Since carbohydrates are richer in oxygen than in fat, $\mathbf{C O}_{2}$ will be produced by decarboxylation without corresponding use of $\mathrm{O}_{2}$, resulting in an RQ higher than 1.0 (Chwalibog, 1995)

The calculation of protein, carbohydrate and fat oxidation could be applied when the RQ is below 1.0 as discussed by Chwalibog and Thorbek (1992). The overesti-mate of the FAT-group from the model calculation in relation to the balance experiment was caused by the assumption that efficiency of $\mathrm{CHO}$ group transformation to the FAT-group (LIPO) was $100 \%$. By giving a lower efficiency, the lipogenesis should reduce the FAT-group and retain fat (RF). Moreover, the difference between the values of RF calculated from the balance experiment and the model of nutrient oxidation will be narrowed This information showed that the method is reliable for use when the RQ is below 1.0 .

This investigation clearly showed that B-agonist L-644,969 decreased the rate of body fat deposition. Likewise, the previous study also found that the lipid percentage and abdominal fat pad was lower in treated broilers than in the control (Merkley and 
Cartwright, 1989). Furthermore, the contribution from different nutrients to RF varied in relation to the level of $B$-agonist. Assuming that the glycogen depots are constant during the balance experiment, the lipogenesis from glucose synthesized from carbon skeletons of degraded amino acid was a minor part, between 6.6 and $8.1 \%$ of the total fat retention. In contrast, the contribution of dietary fat stored directly in the body was in the range from $23.9 \%$ in the control to $7.9 \%$ at the highest level of L- 644,969 , indicating that more body fat was oxidised in $B$-agonist treated animals.

The present study showed that L644,969 improved protein utilization (RP/DP) with no difference in food intake. However, the present diets contained about $26 \%$ of $\mathrm{CP}$ and $19 \mathrm{MJ}$ of ME being higher than the NRC (1994) recommendation for growing broilers. Anderson et al. (1987) suggested that the Bagonist ractopamine was effective in promoting nitrogen retention in pigs when dietary protein was high. This investigation is also in agreement with Reeds et al. (1986), William et at. (1987) and MacRae et al. (1988), all of whom suggested that B-agonist enhanced its effect by suppressing protein breakdown. The $\mathrm{OXP} / \mathrm{DP}$ or $\mathrm{OXP} / \mathrm{HE}$ was decreased and gluconeoge-nesis was restricted in treated animals. Consequently, an increase in $\mathrm{HE}$ was followed by the increase in OXF and the decrease in lipogenesis.

L-644,969 not only increased fat oxidation but also contributed to an increase in the total heat production as a whole (OXF/ $\mathrm{HE}$ ), and there was a tendency to reduce lipogenesis in treated animals. The increase in OXF indicated that the B-agonist increased lipolysis. An in vitro study by Hausman et al. (1989) found that ractopamine stimulates lipolysis and inhibits lipid synthesis in isolated rat adipocytes. Studies in cows (Eisemann ef al, 1988; Stoffel and Mayer, 1993) and chickens (Muir et al, 1985) treated with Bagonist also found an increase in plasma free fatty acid level, indicating a direct stimulation of lipolysis. Furthermore, the decrease in the rate of fat deposition in the $\beta$-agonist treated animals was also partly from the limited carbon skeleton entering the intermediate metabolism since the treated chickens showed lower gluconeogenesis and lower lipogenesis. Reeds and Marsmann (1991) stated that the decrease in fat deposition of the treated animals resulted from a diversion of amino acid carbons away from metabolic pathways that lead to ATP synthesis and partly from an increase in the overall rate of heat production

It seems that B-agonist $\mathrm{L}-644,969$ did not have any effects on carbohydrate metabolism, although the major contribution to heat production was caused by carbohydrate oxidation $(\mathrm{OXCHO} / \mathrm{HE})$. But there was indication that the contribution of carbohydrate to retain fat, $\mathrm{RF}(\mathrm{CHO})$, was numerically increased, suggesting that carbohydrate availability for fat retention was high in treated chickens. There was evidence that the plasma concentration of glucose was also increased in B-agonist treated animals, but the increase was only temporary (Beermann et al., 1986; Eismann et al. 1988, Stoffel and Mayer, 1993).

For animals treated with $\mathrm{B}$-agonists a common finding was an increase in heat production. Measurements with indirect calorimetry showed an increase in total heat production in clenbuterol-treated sheep (MacRae et al, , 1988) and in L-644,969treated bulls (Chwalibog et al., 1996). Furthermore, analysis of comparative slaughter experiments using both clenbuterol and cimaterol showed that treated animals increased heat production (Williams et al. 1987, Kim et al, 1989). An increase in heat production of about $8 \%$ was found in the chickens in the present study at the dose of 1.0 $\mathrm{ppm}$. Moreover, the increase in heat production was only in the part of $\mathrm{OXF} / \mathrm{HE}$ since $\mathrm{OXP} / \mathrm{HE}$ and $\mathrm{OXCHO} / \mathrm{HE}$ were decreased in B-agonist-treated chickens.

The decrease in OXP/HE indicated that protein breakdown was decreased by B-agonist treatment. Rogers and Fagan (1988) found that chicken wing muscle incubated with cimaterol reduced

and leg showed although incubater also foll amino (GLUC) higher $d$ statistica This dec between carbohyd hence de indicated caused consisten Thorbek. who four the main $\mathrm{Fi}$ and decre results of 644,969 , of prote protein $r$ and incre:

Anderso

W:

19

nit

gro

po

$\mathrm{mi}$

Beermanr

$\mathrm{Hc}$

elis

grc

int:

63

Brody, I

Ac.

Brouwer, cal 
reduced protein degradation. Moreover, breast and leg muscie of chickens fed cimaterol also showed the decrease in protein degradation although the responses were less than incubated wings. The decrease in OXP was also followed by a decrease in the flow of amino acid carbons into gluconeogenesis (GLUC).

The RQ was decreased slightly at the higher dose of $1.0 \mathrm{ppm}$ although not being statistically different from the other groups. This decrease was consistent with the switch between OXCHO and OXF as less carbohydrate and more fat was oxidized, hence decreasing the $R Q$ value. The high $R Q$ indicated that the major source of $\mathrm{HE}$ was caused by OXCHO. The present study is consistent with the studies by Chwalibog and Thorbek. (1992) and Chwalibog et al. (1996) who found that oxidation of carbohydrate was the main source for heat production in calves.

Finally, the increase in fat oxidation and decrease in protein oxidation supports the results of previous studies that the $B$-agonist $\mathrm{L}$ 644,969 was highly potent in altering the rates of protein and fat deposition, increasing protein retention, decreasing fat deposition, and increasing lipolysis.

\section{References}

Anderson, D. B., E L Veenhuizen, W. P Waitt, R. E. Paxton, and S. S. Young. 1987. The effect of dietary protein on nitrogen coefficient of metabolizability. growth performance and carcass composition of finishing pigs fed ractopamine. Fed. Proc, 46,1021 (Abstr)

Beermann, D. H. P. J Reeds, F, D DeB Hovell, and D. Kyle. 1986. Cimaterol elicits rapid physiological responses in growing lambs wholly nourished by intragestric infusion. I Anim Sci., 63(Suppl. 1):240

Brody, T. 1994. Nutritional Biochemistry, Academic Press, San Diego.

Brouwer, E. 1958. On simple formulae for calculating the heat expediture and the quantities of carbohydrate and fat metabolized in ruminants, from data on gaseous exchange and urine-N. EEAP Publication, 8: 182-194.

Chwalibog, A and G. Thorbek. 1992. Note about calculation of oxidation of nutrients in pigs. J. Anim. Physiol. Anim. Nutr., 67; 83-86.

Chwalibog, A. 1995, Nutritive Value and Nutrient Requirments of Animals. Dept of Anim. Sci. and Anim. Health, the Royal Veterinary and Agricultural University, Copenhagen.

Chwalibog, A., K. Jensen, and G. Thorbek.. 1996. Oxidation of nutrients in bull calves treated with B-adrenergic agonist. Archives of Animal Nutrition, 49:255-261

Chwalibog, A. 1997. Energy metabolism and requirements in laying hens. World's Poultry Science Association, Proceeding of the 11th European Symposium on Poultry Nutrition, 166-177pp.

Chwalibog, A., K. Jakobsen, S. Heckel, and G. Thorbek 1992 . Estimation of quantitative oxidation and fat retention from carbohydrate, protein and fat in growing pigs. J. Anim. Physiol. Anim. Nutr, 68: 123-135

Eisemann, J. H., G. B. Huntington, and C. L. Ferrell. 1988. Effects of dietary clenbuterol on metabolism of the hindquarters in steers. J. Anim. Sci., 66: 342-353.

Hausman, D. B., R.J. Martin, E. L Veenhuzen, and D. B. Anderson. 1989. Effect of ractopamine on insulin sensitivity and response of isolated rat adiposytes. I Anim Sci., 67: 1455-1464.

Kim, Y S., Y. B Lee, W. N Ganett, and R. H. Dalrymple. 1989 Effects of cimaterol on nitrogen retention and energy utilization in lambs. J. Anim. Sci., 67,674-681.

MacRae, J. C., P. A. Skene, A Connell, V. Buchan, and G. E. Lobley. 1988. The action of $\mathrm{B}$-agonist clenbuterol on protein and energy metabolism in 
fattening wether lambs. Br. J, Nutr., $59: 457-465$.

Merkly, J, W. and A. L. Cartwright. 1989. Adipose tissue depsition and cellularity in cimaterol-treated female broilers Poult. Sci, 68:762-770.

Moloney, A P. P. Allen, D. B. Ross, G Olson, and E. M. Convey. 1990. Growth, feed efficiency and carcass composition of finishing Friesian steers fed the B-adrenergic agonist L- 644,969 . J. Anim. Sci., 68: 1269-1277

Muir, L. A., S. Wien, P. F. Duquette, and G Olson. 1985. Effect of B-adrenergic agonist L-640,033 on lipid metabolism, growth and carcass characteristics of female broilers chickens. J. Anim. Sci., 61 Suppl 1, 263 .

NRC, 1994. Nutrient Requirements of Poultry. 9th ed., pp. 19-34 (Washington, D.C., National Academic Press).

Reeds, P. J., S. M. Hay, P. M. Dorwood, and R. M. Palmer, 1986, Stimulation of muscle growth by clenbuterol: Lack of effect on muscle protein biosynthesis. $\mathrm{Br}$. J. Nutr., 56: 249-258.

Reeds, P. J and H. J. Mersmann 1991. Protein and energy requirments of animals treated with $B$-adrenergic agonist: A discussion. J. Anim, Sci, 69:1542-1550.

Rikhradsson, G., K. A. Johnson, and D. E. Johnson. 1991. Effects of cimaterol on energetics and carcass characteristics of
Suffolk ewe lambs. J. Anim. Sci, 69 : 396-404.

Rogers, K. L. and J. M. Fagan, 1988 . The beta adrenergic agonist cimaterol inhibits protein breakdown in chick skeletal muscle via a nonlysosomal proteolitic mechanism J. Anim. Sci., 66 Suppl. 1: 277.

SAS Institute. 1988. SAS/STAT Guide for Personal Computer. Version 6 Ed. (Cary, NC, SAS Institute Inc.).

Stoffel, B and H. H D Mayer, 1993. Effects of beta-adrenergic clenbuterol in cows: Lipid metabolism, milk production, pharmacokinetics, and residues. J. Anim. Sci., 71(7): 1875-1881.

Williams, P. E. V., L. Pagliani, G. M. Innes, K. Pennie, C. I. Harris, and $P$. Garthwaite, 1987. Effects of a Bagonist (clenbuteron) on growth, carcass composition, protein and energy metabolism of veal calves. $\mathrm{Br}$. J. Nutr., 57: 417-424.

Xiyi, M., J. Shihou, Y. Xiufang, L. Yingjun, and $S$. Qun. 1994. Influence of clenbuterol on energy and protein metabolism in broilers. EAAP Publication, 76:285-288.

Yen, J. T., H. J Mersmann, J. A Nienaber, D. A. Hill and W. G. Pond 1990. Response to cimaterol in genetically obese and lean pigs. J. Anim. Sci. 68: 2698-2706
PENGA

TE

(Callotro) menggune belas eko dibagi $m$ penelitian kume +2 $+35,60 \%$ konsumsi dan kecer dapat mer secara nya BK dan $\mathrm{F}$ daun widt $(\mathrm{P}<0,05)$ : (RW4 = ? cukup ting rumen.

(K:

${ }^{1}$ Fakultas 